\title{
Superoxide induced by a high-glucose concentration attenuates production of angiogenic growth factors in hypoxic mouse mesenchymal stem cells
}

\author{
Toshiaki Ishizuka, Takashi Hinata and Yasuhiro Watanabe \\ Department of Pharmacology, National Defense Medical College, 3-2, Namiki, Tokorozawa, Saitama 359-8513, Japan \\ (Correspondence should be addressed to T Ishizuka; Email: tishizu@ndmc.ac.jp)
}

\begin{abstract}
Previous reports have shown that the paracrine system may be an important mediator in bone-marrow-derived mesenchymal stem cell (MSC) therapy for ischemic diseases. Hyperglycemia and hypoxia have been associated with increased levels of reactive oxygen species; oxidative stress may therefore influence the paracrine effects of MSCs under hypoxic conditions in diabetic patients, although the mechanism underlying this effect remains unknown. Hypoxia-inducible factor $1 \alpha$ (HIF-1 $\alpha)$ regulates the transcription of hypoxia-inducible genes. We determined the effect of high-glucose concentrations on the production of angiogenic growth factors via HIF- $1 \alpha$ induction in hypoxic MSCs. MSCs were cultured with different glucose concentration $(5 \cdot 6,11,20$, or $30 \mathrm{mM})$ for $24 \mathrm{~h}$. The cells were then incubated in a hypoxic chamber $\left(5 \% \mathrm{O}_{2}\right)$ or under normoxia $\left(21 \% \mathrm{O}_{2}\right)$ for 6 or $24 \mathrm{~h}$. Protein levels of HIF-1 $\alpha$, vascular endothelial growth factor $\mathrm{A}_{165}\left(\right.$ VEGF- $\left.\mathrm{A}_{165}\right)$, and
\end{abstract}

platelet-derived growth factor B (PDGF-B) were attenuated by glucose in hypoxic MSCs in a dose-dependent manner. Treatment with MG132, a specific inhibitor of proteasome activity, significantly reversed the inhibitory effect of high-glucose concentrations in hypoxic MSCs. 4-Hydroxyl-tetramethylpiperidin-oxyl (a cell-permeable superoxide scavenger) or Apocynin (a NADPH oxidase inhibitor) significantly reversed glucose-induced attenuation of VEGF-A 165 , PDGF-B, and HIF- $1 \alpha$ protein levels. Stimulation with a high-glucose concentration $(30 \mathrm{mM})$ significantly increased intracellular superoxide levels in hypoxic MSCs. Our results suggest that in hypoxic MSCs the increase in intracellular superoxide levels induced by high-glucose concentrations may attenuate hypoxia-induced HIF- $1 \alpha$ expression, which in turn attenuates hypoxiainduced VEGF-A 165 and PDGF-B transcription.

Journal of Endocrinology (2011) 208, 147-159

\section{Introduction}

Several clinical trials have shown that the administration of autologous bone-marrow-derived cells induces therapeutic angiogenesis in patients with ischemic heart disease and peripheral arterial disease (Strauer et al. 2002, Tateishi-Yuyama et al. 2002, Stamm et al. 2003). Bonemarrow-derived mesenchymal stem cells (MSCs) are a potent source of critical growth factors such as vascular endothelial growth factor (VEGF) and fibroblast growth factor-2 (FGF-2), which protect ischemic tissue (Wang et al. 2006). MSCs also protect the mouse myocardium or hindlimb from ischemic injury through elevated release of VEGF (Kinnaird et al. 2004a, Tang et al. 2004). These findings suggest that the paracrine system may be an important mediator of MSC therapeutic efficacy in ischemic diseases.

Early studies indicated that the ability of transplanted bone marrow cells (BMCs) to promote neovascularization in the ischemic hindlimb is attenuated in diabetic animal models (Hirata et al. 2003, Tamarat et al. 2004, Sica et al. 2006).
Li et al. (2006) showed that VEGF production and therapeutic angiogenesis induced by BMCs taken from obese diabetic rats are significantly lower than those of BMCs taken from control rats. Concomitant treatment with antioxidants significantly ameliorated ischemia-induced angiogenesis by i.v. injection of autologous BMCs in the diabetic hindlimb (Sica et al. 2006). Injected BMCs isolated from antioxidant-treated diabetic mice increased postischemic neovascularization by 1.5-fold as compared to those from untreated diabetic mice (Ebrahimian et al. 2006). The effects of hyperglycemia or hypoxia have been associated with increased levels of reactive oxygen species (ROS; Waypa et al. 2001, Brownlee 2005, Gao \& Wolin 2008). Oxidative stress may therefore affect the paracrine influence of bone-marrow-derived cells under hypoxic conditions in diabetic patients, but the precise mechanism underlying these effects remains unknown.

Hypoxia caused mouse MSCs to increase the expression and secretion of VEGF (Kinnaird et al. 2004b, Wang et al. 2007). Hypoxia-inducible gene transcription is regulated by hypoxia-inducible factor-1 (HIF-1), which is essential for 
adaptive cellular responses to hypoxia. HIF- $1 \alpha, \alpha$ subunit of HIF-1, is hydroxylated under normoxia but is stabilized under hypoxia. HIF- $1 \alpha$ regulates the transcription of VEGF, platelet-derived growth factor (PDGF), and FGF-2 in response to hypoxia (Nilsson et al. 2004, Calvani et al. 2006, Copple et al. 2009); therefore, HIF-1 $\alpha$ induction may enhance the production of these proteins in mouse MSCs. In previous studies, the effects of high-glucose concentrations on HIF- $1 \alpha$ expression in various mammalian cells were examined. In human dermal microvascular endothelial cells, a high-glucose concentration impaired hypoxia-independent protection of HIF- $1 \alpha$ against proteasomal degradation (Catrina et al. 2004). In rat kidney mesangial cells, a highglucose concentration stimulated HIF-1 $\alpha$ expression and VEGF secretion (Xia et al. 2007). Ceradini et al. (2008) showed that in hypoxic mouse dermal fibroblasts, intracellular ROS induced by a high-glucose concentration reduced HIF-1 $\alpha$ binding to DNA promoters without affecting HIF- $1 \alpha$ expression. The inconsistencies in these results may be due to the differences in the examined cell types. The effect of a high-glucose concentration on HIF- $1 \alpha$ expression in MSCs has not been previously studied and requires clarification. Earlier studies in acute myocardial infarction models showed that transplantation of bone-marrow-derived cells into the peri-infarction region improved collateral blood flow and cardiac function versus transplantation into the infarction region (Kinnard et al. 2004a,b, Yoshioka et al. 2005). This finding may be due to the lower reactivity of host vascular endothelial cells to growth factors in severe ischemic regions. The average blood flow ratio in periinfarction to nonischemic regions of experimental myocardial infarction models or stroke patients is $\sim 25 \%$ (Odano et al. 1993, Yoshioka et al. 2005). Thus, we need to clarify whether oxidative stress induced by a high-glucose concentration under moderate, rather than severe hypoxia $\left(5 \% \mathrm{O}_{2} ; 25 \%\right.$ of normal oxygen concentration), affects the production of angiogenic growth factors through HIF-1 $\alpha$ induction in MSCs.

\section{Materials and Methods}

\section{Animals}

Male, 5-week-old C57Bl/6 mice were used (Japan SLC, Inc., Hamamatsu, Japan) in accordance with the guidelines of the Japanese Association for Laboratory Animal Science, which comply with international rules and policies.

\section{Preparation of mouse bone marrow mesenchymal stem cells}

Isolation of mouse MSCs has previously been described (Peister et al. 2004). In brief, BMCs were harvested from 16 male C57Bl/6 mice (5-week-old) by flushing out the femoral and tibial cavities with a complete culture medium that included the following: $\alpha$-minimal essential medium,
$10 \%$ fetal bovine serum, $100 \mathrm{U} / \mathrm{ml}$ penicillin, and $100 \mu \mathrm{g} / \mathrm{ml}$ streptomycin (all obtained from Invitrogen). Cells were passed through a $30 \mu \mathrm{m}$ nylon mesh to remove any remaining clumps of bone marrow. Cells were washed with complete medium and centrifuged for $5 \mathrm{~min}$ at $50 \mathrm{~g}$ The cell pellets were re-suspended and cultured in $100 \mathrm{~mm}$ dishes with complete medium at $37^{\circ} \mathrm{C}$ and $5 \% \mathrm{CO}_{2}$. MSCs selectively adhere to the polystylene surface, and non-adherent cells were removed 2 days after plating. Adherent cells were further propagated through $4-5$ passages.

To identify the cells as MSCs, the cells were analyzed by flow cytometry using FITC-conjugated rat anti-mouse cluster of differentiation 44 (CD44), rabbit anti-mouse CD105, rat anti-mouse CD34, and rat anti-mouse CD45 (all obtained from AbD Serotec, Oxford, UK). The cells were analyzed using a flow cytometer FACS Calibur (BectonDickinson, Rutherford, NJ, USA) equipped with a $488 \mathrm{~nm}$ argon ion laser and Cell Quest software (Becton-Dickinson). Signals were obtained using a $530 \mathrm{~nm}$ bandpass FITC filter. The determination was based on the mean fluorescence intensity of 5000 cells.

To evaluate the differentiation potential of the MSCs toward osteoblasts, subconfluent MSCs were treated with bone morphogenetic protein $2(3 \mathrm{nM})$, ascorbic acid $(50 \mu \mathrm{g} / \mathrm{ml})$, and $\beta$-glycerol phosphate $(10 \mathrm{mM})$ for 7 days. The cells were washed with PBS, fixed with $4 \%$ paraformaldehyde for $20 \mathrm{~min}$, and stained for alkaline phosphatase with 5-bromo-4-chloro-3-indolyl phosphate/ $p$-nitroblue tetrazolium chloride $(0.1 \mathrm{mg} / \mathrm{ml}$; Abcam, Cambridge, MA, USA) for $2 \mathrm{~h}$ at room temperature. To evaluate the differentiation potential of MSCs toward adipocytes, subconfluent MSCs were treated with insulin $(100 \mathrm{nM})$, indomethacin $(50 \mu \mathrm{M})$, and dexamethasone $(100 \mathrm{nM})$ for 7 days. The cells were washed twice with PBS, fixed with 10\% formaldehyde for $20 \mathrm{~min}$, and stained with $0 \cdot 18 \%$ Oil Red O solution (60\% isopropyl alcohol) for $20 \mathrm{~min}$ at room temperature.

When cultures became confluent, the cells were harvested and re-plated at a density of $1 \times 10^{6}$ cells/dish. After $24 \mathrm{~h}$ incubation, the culture medium was discarded and the cells were treated with normal glucose concentration $(5.6 \mathrm{mM})$, a high-glucose concentration $(11,20$, or $30 \mathrm{mM})$, or $24 \cdot 4 \mathrm{mM}$ mannitol plus $5.6 \mathrm{mM}$ glucose. After $24 \mathrm{~h}$, cells were incubated in an Invivo 2300 Hypoxia Chamber (Ruskinn Technology, Pencoed, UK) at $37^{\circ} \mathrm{C}, 5 \% \mathrm{CO}_{2}$, and $5 \% \mathrm{O}_{2}$ for 6 or $24 \mathrm{~h}$. To avoid re-oxygeneration of the hypoxia-treated cells, we collected total RNA, the cell lysates, and the culture supernatants in an Invivo 2300 Hypoxia Workstation (Ruskinn Technology) at $37^{\circ} \mathrm{C}, 5 \% \mathrm{CO}_{2}$, and $5 \% \mathrm{O}_{2}$. All other cell cultures were incubated under normoxia $\left(37^{\circ} \mathrm{C}, 5 \% \mathrm{CO}_{2}\right.$, and $\left.21 \% \mathrm{O}_{2}\right)$ for 6 or $24 \mathrm{~h}$. To assess cell viability, the total number of surviving cells was counted after staining with $0 \cdot 4 \%$ trypan blue solution (Sigma) and the cell survival rate was calculated as the percentage of the total re-plated cells. 


\section{Real-time reverse transcription-PCR}

After $6 \mathrm{~h}$ exposure to normoxic or hypoxic conditions, total RNA from treated cells was extracted using the RNeasy Mini kit (Qiagen) according to the manufacturer's instructions. After spectrophotometric quantification, reverse transcription was carried out using random primers and MultiScribe reverse transcriptase (Applied Biosystems, Foster, CA, USA). The cDNA was quantified by real-time PCR using TaqMan Universal PCR master mix and the ABI PRISM 7900HT Sequence Detection System (Applied Biosystems). Based on published reports, the following primers and TaqMan probes were used: $\beta$-actin, forward: 5'-ATGCTCCCCGGGCTGTAT- $3^{\prime}$; reverse: 5'-TCACCCACATAGGAGTCCTTCTG-3'; TaqMan probe: $5^{\prime}$-(FAM)-ATCACACCCTGGTGCCTAGGGCG-(TAMRA)-3'; HIF-1 $\alpha$, forward: 5'-AGACAGACAAAGCTCATCCAAGG-3'; reverse: 5'-GCGAAGCTATTGTCTTTGGGTTTAA-3'; TaqMan probe: $5^{\prime}$-(FAM)-CTGCCACTTTGAATCAAAGAAATACTGTTCCTGAG-(TAMRA)-3'; VEGF-A 165 , forward: 5'-GCACTGGACCCTGGCTTTACT-3'; reverse: $5^{\prime}$-ACTTGATCACTTCATGGGACTTCTG-3'; TaqMan probe: $5^{\prime}$-(FAM)-CCATGCCCAGTGGTCCCAGGCTG-(TAMRA)-3'; PDGF-B, forward: 5'-CATCCGCTCCTTTGATGATCTT-3'; reverse: 5'-ATGAGCTTTCCAACTCGACTCC-3'; TaqMan probe: $5^{\prime}$-(FAM)-CCTGCTGCACAGAGAGACTCCGTAGATGAA-(TAMRA)-3'. The PCR amplification profile was as follows: $50{ }^{\circ} \mathrm{C}, 2 \mathrm{~min} ; 95^{\circ} \mathrm{C}$, $10 \mathrm{~min}$; and 40 cycles of denaturing at $95^{\circ} \mathrm{C}$ for $15 \mathrm{~s}$, and annealing/extension for $1 \mathrm{~min}$ at $60^{\circ} \mathrm{C}$. The threshold cycle $\left(C_{\mathrm{t}}\right)$, the cycle at which emission rises above the baseline, was determined for both the target gene and $\beta$-actin for each sample, and the relative quantity of target gene transcript was determined by using a comparative $C_{t}$ method as described in the ABI Prism sequence detection system manual (Applied Biosystems). For each sample, $\Delta C_{t}$ was calculated by subtracting each target $C_{\mathrm{t}}$ value from the mean $\beta$-actin $C_{\mathrm{t}}$ value. Relative quantification of the target transcript levels was determined by evaluating the expression $2^{-\Delta \Delta C_{\mathrm{t}}}$, where $\Delta \Delta C_{\mathrm{t}}$ represents the subtraction of the $\Delta C_{\mathrm{t}}$ determined for the control from that determined for each treatment group.

\section{Western blot analysis}

After 6 or $24 \mathrm{~h}$ exposure to normoxic or hypoxic conditions, the cells were lysed in cold buffer $(50 \mathrm{mM}$ Tris $(\mathrm{pH} 7 \cdot 4)$, $150 \mathrm{mM} \mathrm{NaCl}, 2 \mathrm{mM}$ EDTA, 1\% Triton X-100, $10 \mathrm{mM}$ $\mathrm{Na}_{4} \mathrm{P}_{2} \mathrm{O}_{7}, 20 \mathrm{mM} \mathrm{NaF}, 1 \mathrm{mM} \mathrm{Na} \mathrm{VO}_{4}, 10 \mathrm{mg} / \mathrm{ml}$ aproti$\mathrm{nin})$; and centrifuged at $10000 \mathrm{~g}$ for $15 \mathrm{~min}$. The protein extracts $(15 \mu \mathrm{g})$ were electrophoresed on a $7 \cdot 5-15 \%$ SDS-polyacrylamide gel and blotted on a polyvinylidene difluoride membrane with a semidry blotting apparatus. After blocking, primary antibodies were applied at the following concentrations: rabbit anti-mouse VEGF-A 165 (Santa Cruz Biotechnology, Inc., Santa Cruz, CA, USA), rabbit antimouse PDGF-B (Santa Cruz), rabbit anti-mouse FGF-2
(Santa Cruz), goat anti-mouse gp91 ${ }^{\text {phox }}$ (Santa Cruz), goat anti-mouse xanthine oxidase (XO; Santa Cruz), rabbit antimouse $\mathrm{p} 22^{\text {phox }}$ (Santa Cruz), and rabbit anti-mouse $\beta$-actin (Acris Antibodies $\mathrm{GmbH}$, Hiddenhausen, Germany) at $1 \mu \mathrm{g} / \mathrm{ml}$; rabbit anti-mouse HIF-1 $\alpha$ (Affinity Bioreagents, Golden, CO, USA) at $0 \cdot 25 \mu \mathrm{g} / \mathrm{ml}$. Secondary peroxidaseconjugated antibodies were added and immunoreactive proteins were visualized by the ECL Western Blotting detection kit (Amersham Biosciences). Densitometry of the immunoreactive bands was performed by a luminescent image analyzer (LAS 3000; Fuji Film, Tokyo, Japan) and software for image analysis (Multi Gauge version 3.1; Fuji Film). The density of the bands was normalized to $\beta$-actin as the internal standard.

\section{ELISA}

After $24 \mathrm{~h}$ exposure to normoxic or hypoxic conditions, MSC supernatants were collected. VEGF-A 165 and PDGF-B were quantified by ELISA using a commercial ELISA kit (Invitrogen), according to the manufacturer's instructions. All samples and standards were measured in duplicate. The protein content was determined by the Bradford method (Bradford 1976), with BSA as the standard. The VEGF-A 165 or PDGF-B content in the supernatant was normalized to the protein content of the cell layer.
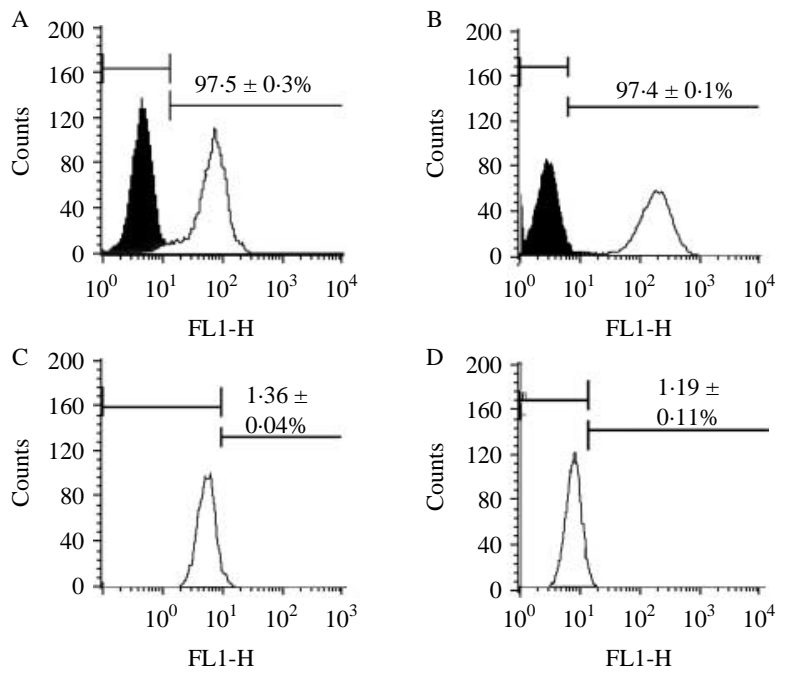

Figure 1 Expression of CD44, CD105, CD34, and CD45 on mouse bone-marrow-derived cells. Representative histograms show the expression of CD44 (A), CD105 (B), CD34 (C), and CD45 (D) in mouse bone-marrow-derived cells evaluated by single-color flow cytometry as described in section 'Materials and Methods'. Log fluorescence (horizontal axis) for the antibodies of CD44, CD105, CD34, or CD45 is demonstrated in the white histograms, and the isotype control peak is black. Values represent the percentage of cells expressing CD44, CD105, CD34, or CD45 (mean \pm S.E.M.; $n=4$ ). 
Flow cytometric determination of intracellular superoxide levels

Intracellular superoxide levels were measured by flow cytometry as the fluorescence of ethidium, which represents the superoxide-sensitive oxidation products of dihydroethidium (Sharikabad et al. 2001). Cells were incubated for $10 \mathrm{~min}$ with a dihydroethidium probe $(2 \mathrm{mM}, 0 \cdot 15 \%$ dimethylsulfoxide) at $37^{\circ} \mathrm{C}$. Cells were fixed with $1 \%$ paraformaldehyde and protected from light at $4{ }^{\circ} \mathrm{C}$. A flow cytometer FACS Calibur (Becton-Dickinson), equipped with a $488 \mathrm{~nm}$ argon ion laser and Cell Quest software (Becton-Dickinson), was used to measure superoxide levels. Signals were obtained by using a $575 \mathrm{~nm}$ bandpass filter for ethidium. Determinations were based on the mean fluorescence intensity of 5000 cells.

\section{Short interfering $R N A$ treatment}

Subconfluent cells were transfected with short interfering RNAs (siRNAs) using siPORT NeoFX Transfection Agent (Ambion, Austin, TX, USA) according to the manufacturer's instructions. Two kinds of siRNA targeting HIF-1 $\alpha$ (sense, 5'-GCUUCUGUUAUGAGGCUCATT-3'; antisense,
5'-UGAGCCUCA-UAACAGAAGCTT-3', GenBank accession number, NM_010431 exon 2), (sense, 5'-GGAUACAAGCUGCCUUUUU-TT-3'; antisense, 5'-AAAAAGGCAGCUUGUAUCCTC-3', GenBank accession number, NM_010431 exon 9), and nontargeting siRNA (Silencer Negative Control siRNA) were purchased from Ambion. Mock control cells were transfected without oligonucleotides under the same conditions. After transfection, the cells were grown for $24 \mathrm{~h}$ and then exposed to normoxic or hypoxic conditions with or without MG132 (5 $\mu \mathrm{M}$; a specific inhibitor of proteasome activity). The cells were lysed and whole-cell lysates were extracted as described above.

Preparation of mitochondria-enriched fractions and measurement of mitochondrial complexes I and III activity

After $24 \mathrm{~h}$ exposure to normoxic or hypoxic conditions, cells were disrupted mechanically by a glass/Teflon homogenizer and centrifuged at $4500 \mathrm{~g}$ for $10 \mathrm{~min}$. The mitochondria-enriched pellets were frozen in $10 \mathrm{mM}$ Tris, $\mathrm{pH} 7 \cdot 6$, and kept at $-80^{\circ} \mathrm{C}$.
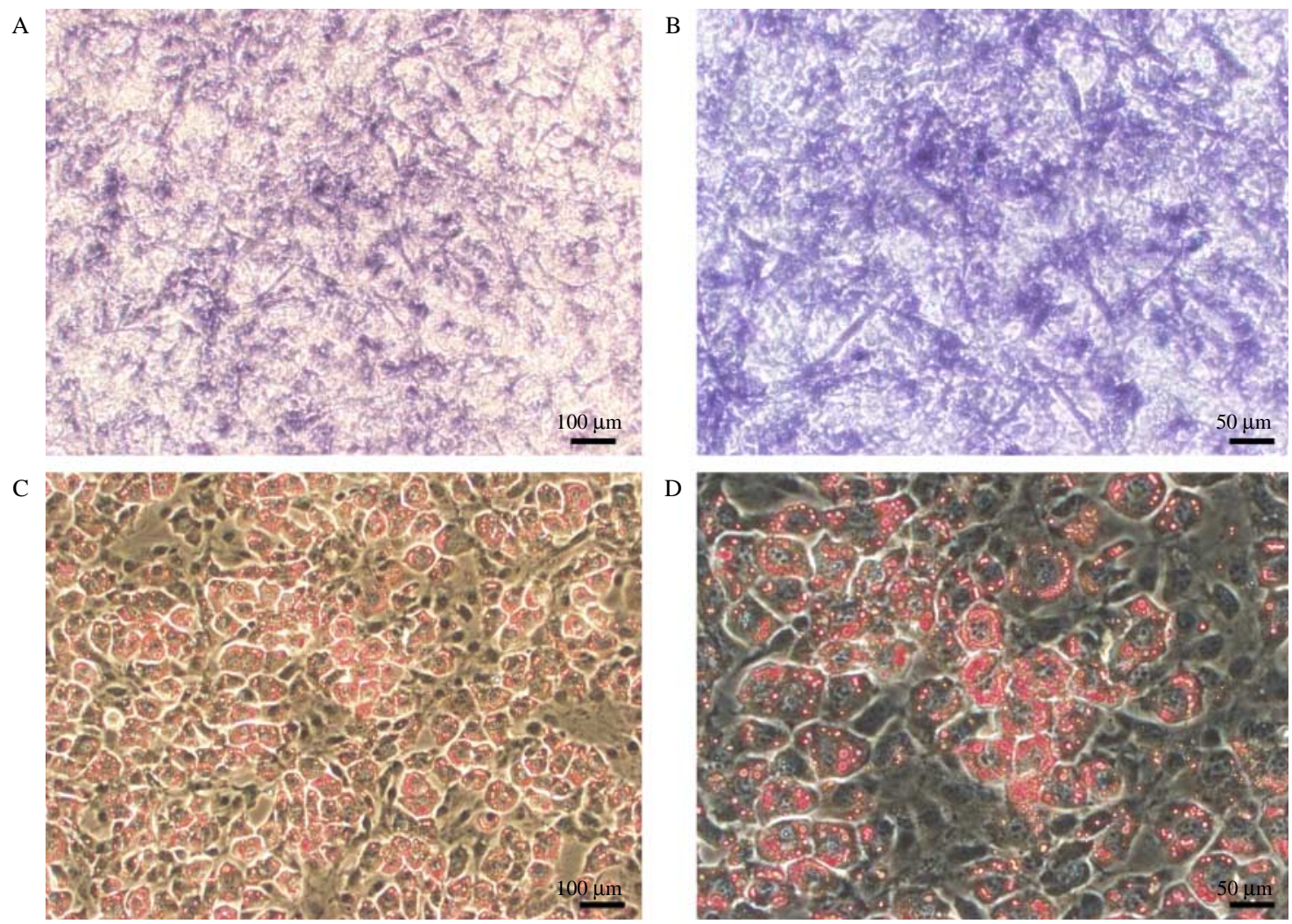

Figure 2 Differentiation potential of mouse bone-marrow-derived cells. (A and B) To evaluate the differentiation potential of mouse bone-marrow-derived cells toward osteoblasts, subconfluent cells were treated with bone morphogenetic protein 2 $(3 \mathrm{nM})$, ascorbic acid $(50 \mu \mathrm{g} / \mathrm{ml})$, and $\beta$-glycerol phosphate $(10 \mathrm{mM})$ for 7 days. Representative photomicrographs reveal positive staining of cuboidal cells for alkaline phosphatase. (C and D) To evaluate the differentiation potential of the cells toward adipocytes, subconfluent cells were treated with insulin $(100 \mathrm{nM})$, indomethacin $(50 \mu \mathrm{M})$, and dexamethasone $(100 \mathrm{nM})$ for 7 days. Representative photomicrographs reveal positive staining with Oil Red O. Bars represent $100 \mu \mathrm{m}$ (A and $C$ ) and $50 \mu \mathrm{m}$ (B and D). Full colour version of this figure available via http://dx.doi.org/10.1677/JOE-10-0305. 
Complexes I and III activity were assayed by previously established methods (Jarreta et al. 2000, Janssen et al. 2007). Complex I activity (NADH-decylubiquinone oxidoreductase) was measured at $340 \mathrm{~nm}$ (U-3010 Spectrophotometer, Hitachi) using the acceptor 2,3-dimethoxy-5-methyl-6-n-decyl-1,4-benzoquinone (80 mM) and $200 \mu \mathrm{M}$ NADH as donor, in $10 \mathrm{mM}$ Tris (pH 8.0) buffer containing $1 \mathrm{mg} / \mathrm{ml}$ BSA, $0 \cdot 24 \mathrm{mM} \mathrm{KCN}$, and $0.4 \mu \mathrm{M}$ antimycin $\mathrm{A}$ for $5 \mathrm{~min}$. To permeabilize the mitochondrial internal membrane to $\mathrm{NADH}$, the sample was incubated in distilled water for $3 \mathrm{~min}$ at $37^{\circ} \mathrm{C}$. Complex III activity (ubiquinol cytochrome $c$ reductase) was measured at $550 \mathrm{~nm}$ using $40 \mu \mathrm{M}$ oxidized cytochrome $c$ as the acceptor and $80 \mu \mathrm{M}$ decylubiquinol as the donor in $10 \mathrm{mM} \mathrm{KH}_{2} \mathrm{PO}_{4}$
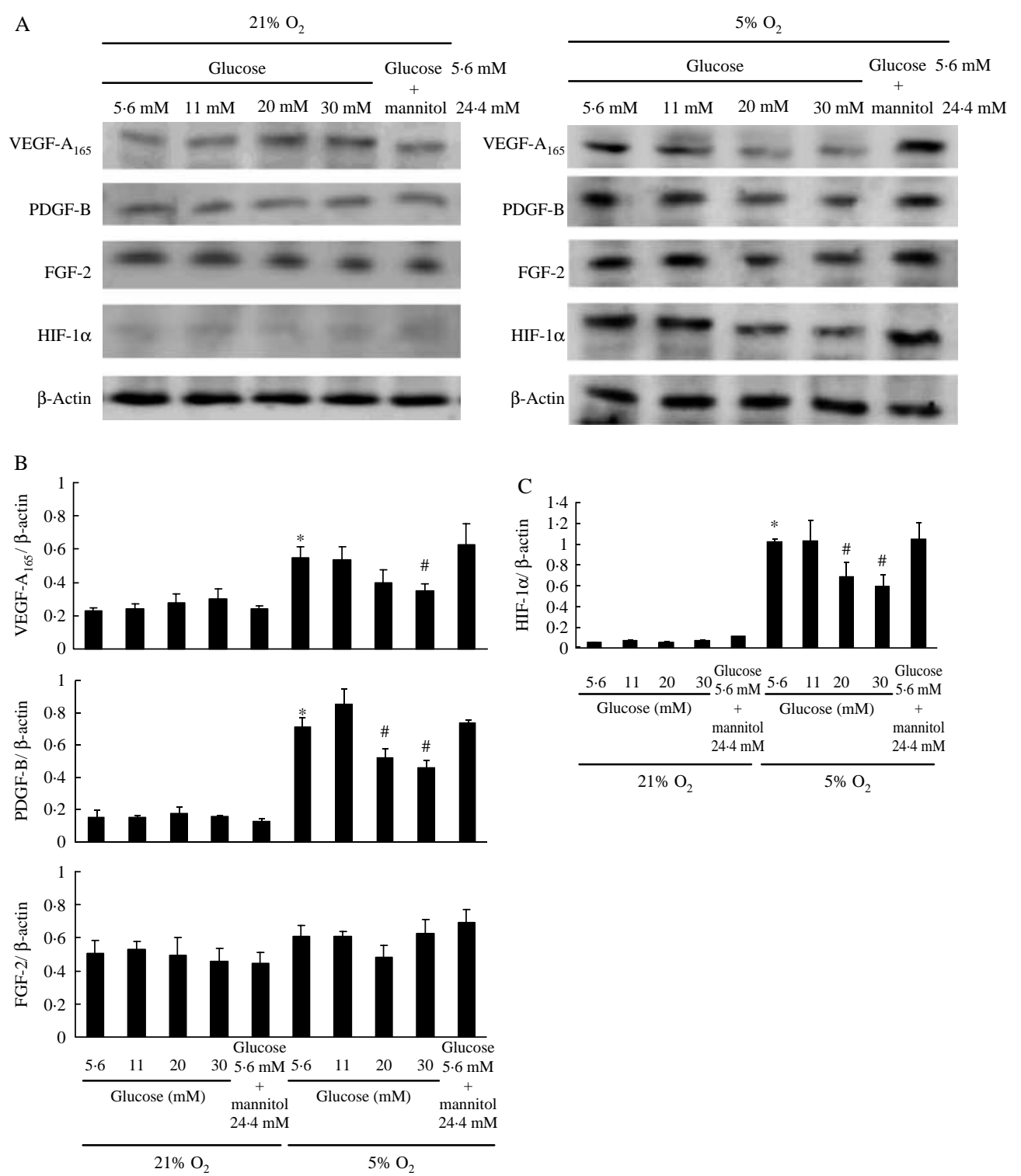

Figure 3 Effects of a high-glucose concentration on the expression of VEGF- $\mathrm{A}_{165}$, PDGF-B, FGF-2, and HIF- $1 \alpha$ in mouse mesenchymal stem cells under normoxic or hypoxic conditions. MSCs were treated with normal glucose $(5.6 \mathrm{mM})$, high glucose $(11,20$, or $30 \mathrm{mM})$, or $5.6 \mathrm{mM}$ glucose $+24.4 \mathrm{mM}$ mannitol. After $24 \mathrm{~h}$, the cells were incubated at normoxia $\left(21 \% \mathrm{O}_{2}\right)$ or in a hypoxic chamber $\left(5 \% \mathrm{O}_{2}\right)$ for $24 \mathrm{~h}$. VEGF-A 165 , PDGF-B, FGF-2, and HIF-1 $\alpha$ protein levels were determined by western blot analysis as described in section 'Materials and Methods'. (A) Representative ECL gel documents show the protein expression in MSCs under normoxic or hypoxic conditions for $24 \mathrm{~h}$. The bands of $\beta$-actin in the lower panel are shown for internal standards. (B and C) Bar graphs show quantitative analysis of the bands by densitometry. Values were normalized to the optical density values of $\beta$-actin bands. Data represent means \pm s.E.M. $(n=4) .{ }^{*} P<0 \cdot 01$ versus MSCs treated with $5.6 \mathrm{mM}$ glucose at normoxia. ${ }^{\sharp} P<0 \cdot 05$ versus hypoxic MSCs treated with $5.6 \mathrm{mM}$ glucose. 


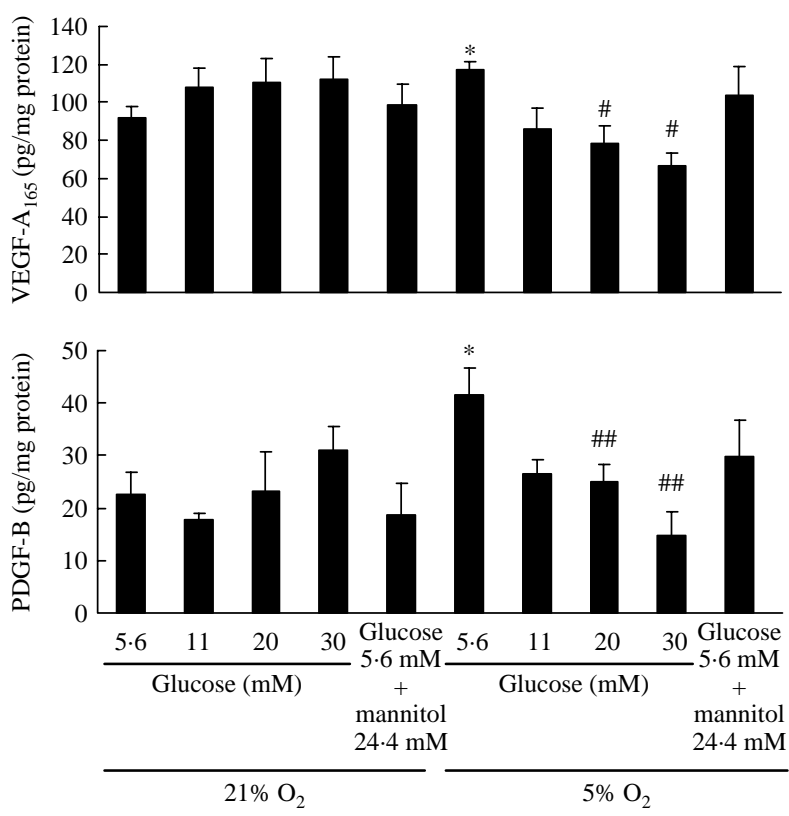

Figure 4 Effects of a high-glucose concentration on the production of VEGF-A 165 or PDGF-B in mouse mesenchymal stem cells under normoxic or hypoxic conditions. MSCs were treated with normal glucose $(5.6 \mathrm{mM})$, high glucose $(11,20$, or $30 \mathrm{mM})$, or $5.6 \mathrm{mM}$ glucose $+24.4 \mathrm{mM}$ mannitol. After $24 \mathrm{~h}$, the cells were incubated at normoxia $\left(21 \% \mathrm{O}_{2}\right)$ or in a hypoxic chamber $\left(5 \% \mathrm{O}_{2}\right)$ for $24 \mathrm{~h}$. Culture supernatants were collected. The production of VEGF-A 165 or PDGF-B in the culture supernatants was determined by ELISA. Data represent means \pm S.E.M. $(n=4) .{ }^{*} P<0 \cdot 01$ versus MSCs treated with $5.6 \mathrm{mM}$ glucose at normoxia. ${ }^{\sharp} P<0 \cdot 05 ;{ }^{\#} P<0.01$ versus hypoxic MSCs treated with $5.6 \mathrm{mM}$ glucose.

$(\mathrm{pH} 7 \cdot 8), 1 \mathrm{mg} / \mathrm{ml} \mathrm{BSA}$, and $2 \mathrm{mM}$ EDTA, in the presence of $0 \cdot 24 \mathrm{mM} \mathrm{KCN}, 4 \mu \mathrm{M}$ rotenone, and $0.2 \mathrm{mM}$ ATP for $2 \mathrm{~min}$. The addition of $1 \mu \mathrm{M}$ antimycin A allowed us to distinguish between the reduction of cytochrome $c$ catalyzed by complex III and the nonenzymatic reduction of cytochrome $c$ by reduced quinone.

\section{Proteasome activity assay}

After $6 \mathrm{~h}$ exposure to normoxic or hypoxic conditions, cells were lysed in cold buffer (50 mM Tris ( $\mathrm{pH} \mathrm{7 \cdot 4),} 150 \mathrm{mM}$ $\mathrm{NaCl}, 2 \mathrm{mM}$ EDTA, 1\% Triton X-100, $10 \mathrm{mM} \mathrm{Na}_{4} \mathrm{P}_{2} \mathrm{O}_{7}$, $20 \mathrm{mM} \mathrm{NaF}, 1 \mathrm{mM} \mathrm{Na} \mathrm{VO}_{4}$ ) and centrifuged at $10000 \mathrm{~g}$ for $15 \mathrm{~min}$. Proteasome activity in the cell lysates was evaluated by the Proteasome Activity Assay kit (Chemicon International, Inc., Billerica, MA, USA). The assay is based on detection of fluorophore 7-amino-4-methylcoumarin (AMC) after the cleavage from the labeled substrate Leu-Leu-Val-Tyr-AMC by the proteasome (Meng et al. 1999). Free AMC fluorescence is quantified using a fluorometer (PerkinElmer, Waltham, MA, USA). All samples and standards were measured in duplicate. The data in the cell lysates were normalized to the protein contents.
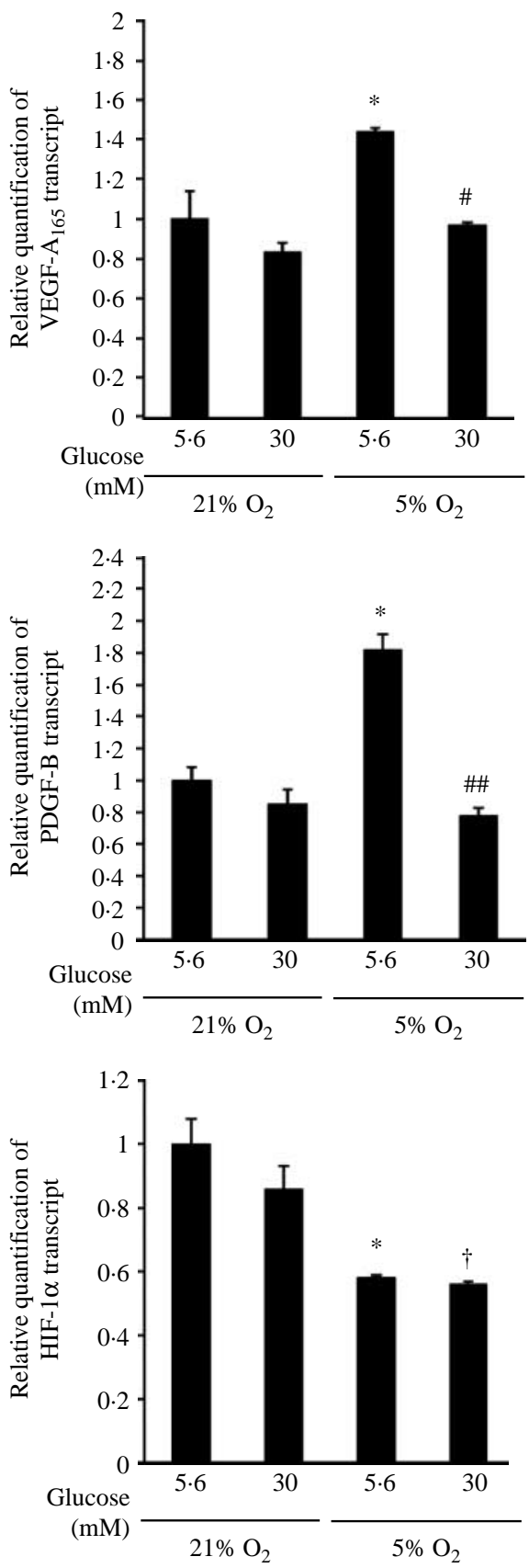

Figure 5 Effects of a high-glucose concentration on the mRNA expression of VEGF- $\mathrm{A}_{165}$, PDGF-B, and HIF-1 $\alpha$ in mouse mesenchymal stem cells under normoxic or hypoxic conditions. MSCs were treated with normal glucose $(5.6 \mathrm{mM})$ or high glucose $(30 \mathrm{mM})$. After $24 \mathrm{~h}$, the cells were incubated at normoxia $\left(21 \% \mathrm{O}_{2}\right)$ or in a hypoxic chamber $\left(5 \% \mathrm{O}_{2}\right)$ for $6 \mathrm{~h}$. After $6 \mathrm{~h}$ exposure to normoxic or hypoxic conditions, total RNA was extracted. VEGF- $\mathrm{A}_{165}$, PDGF-B, and HIF-1 $\alpha$ transcript levels were determined using real-time RT-PCR and normalized to a control value $\left(5.6 \mathrm{mM}, 21 \% \mathrm{O}_{2}\right)$ as described in section 'Materials and Methods'. Data represent means \pm s.E.M. $(n=4)$. ${ }^{*} P<0 \cdot 01$ versus MSCs treated with $5.6 \mathrm{mM}$ glucose at normoxia. ${ }^{\dagger} P<0 \cdot 01$ versus MSCs treated with $30 \mathrm{mM}$ glucose at normoxia. ${ }^{\ddagger} P<0 \cdot 05 ;{ }^{\# \#} P<0 \cdot 01$ versus hypoxic MSCs treated with 5.6 mM glucose. 


\section{Statistical analysis}

All results were expressed as means \pm s.E.M. Comparisons between the means of multiple groups were analyzed by oneway ANOVA and Scheffe's multiple comparison test. The number of MSCs from different animals is shown as $n$. In all tests, differences were considered statistically significant at $P<0 \cdot 05$.

\section{Results}

Identification of bone-marrow-derived cells with MSCs

Flow cytometry showed that the primary bone-marrowderived cells were CD34 ${ }^{-}, \mathrm{CD} 44^{+}, \mathrm{CD} 45^{-}$, and CD $105^{+}$ (Fig. 1). To evaluate the differentiation potential toward osteoblasts, subconfluent cells were treated with bone morphogenetic protein $2(3 \mathrm{nM})$, ascorbic acid $(50 \mu \mathrm{g} / \mathrm{ml})$, and $\beta$-glycerol phosphate $(10 \mathrm{mM})$ for 7 days. Photomicrographs revealed positive staining of cuboidal cells for alkaline phosphatase (Fig. 2A and B). To evaluate the differentiation potential toward adipocytes, subconfluent cells were treated with insulin $(100 \mathrm{nM})$, indomethacin $(50 \mu \mathrm{M})$, and dexamethasone $(100 \mathrm{nM})$ for 7 days. Photomicrographs revealed positive staining with Oil Red $\mathrm{O}$ (Fig. 2C and D). These findings suggest that the bone-marrow-derived cells have the same properties as mouse MSCs.

Effect of a high-glucose concentration on $V E G F-A_{165}$, PDGF-B, and FGF-2 expression in MSCs under normoxic or hypoxic conditions

The MSC survival rate under normoxic or hypoxic conditions was unaffected by high-glucose concentrations (data not shown). Exposure to a high-glucose level under normoxia did not affect cellular protein levels of VEGF-A 165 , PDGF-B, or FGF-2 (Fig. 3A and B). In contrast, stimulation with a high-glucose concentration $(30 \mathrm{mM})$ under hypoxic conditions significantly attenuated VEGF-A 165 and PDGF-B protein levels. This was not due to an osmotic effect because $24.4 \mathrm{mM}$ mannitol plus $5.6 \mathrm{mM}$ glucose did not attenuate protein levels of VEGF-A 165 or PDGF-B. In contrast, FGF-2 protein levels were unaffected by high-glucose concentrations under hypoxic conditions.

Exposure to high-glucose concentrations under normoxia did not affect the cellular production of VEGF-A 165 or PDGF-B in the MSCs (Fig. 4), but under hypoxic conditions stimulation with high-glucose concentrations (30 mM) significantly attenuated VEGF-A 165 and PDGF-B production. VEGF-A 165 and PDGF-B production were not attenuated by $24.4 \mathrm{mM}$ mannitol plus $5.6 \mathrm{mM}$ glucose.

Exposure to high-glucose concentrations under normoxia did not affect the mRNA level of VEGF-A 165 or PDGF-B in the MSCs (Fig. 5), but under hypoxic conditions a highglucose concentration $(30 \mathrm{mM})$ significantly attenuated the mRNA expression of VEGF-A 165 and PDGF-B.
Effect of a high-glucose concentration on HIF- $1 \alpha$ expression in MSCs under hypoxic conditions

Under normoxia, HIF-1 $\alpha$ protein was scarcely detected by western blot analysis of MSC extracts and exposure to highglucose concentrations had no effect on HIF-1 $\alpha$ protein levels (Fig. 3A and C). In contrast, stimulation with a high-glucose concentration $(30 \mathrm{mM})$ significantly inhibited hypoxiainduced accumulation of HIF- $1 \alpha$ protein.

To study the processes by which stimulation with a highglucose concentration interferes with $\mathrm{HIF}-1 \alpha$ upregulation in hypoxia, the effect of a high-glucose concentration on $H I F-1 \alpha$ mRNA levels under normoxia and hypoxia was investigated. Exposure to a high-glucose concentration did not affect $H I F-1 \alpha$ mRNA content under either normoxia or hypoxia, indicating that stimulation with a high-glucose concentration does not regulate HIF-1 $\alpha$ transcription (Fig. 5).

Previous studies have suggested that proteasome-mediated degradation may regulate $\mathrm{HIF}-1 \alpha$ expression and function (Salceda \& Caro 1997, Kallio et al. 1999). Thus, the inhibitory effect of high-glucose concentrations on HIF- $1 \alpha$ protein levels in hypoxic MSCs in the presence or absence of MG132, a specific inhibitor of proteasome activity, was studied. Treatment with $5 \mu \mathrm{M}$ MG132 significantly reversed the inhibitory effect of a high concentration of glucose on HIF-1 $\alpha$ protein levels in hypoxic MSCs (Fig. 6), but

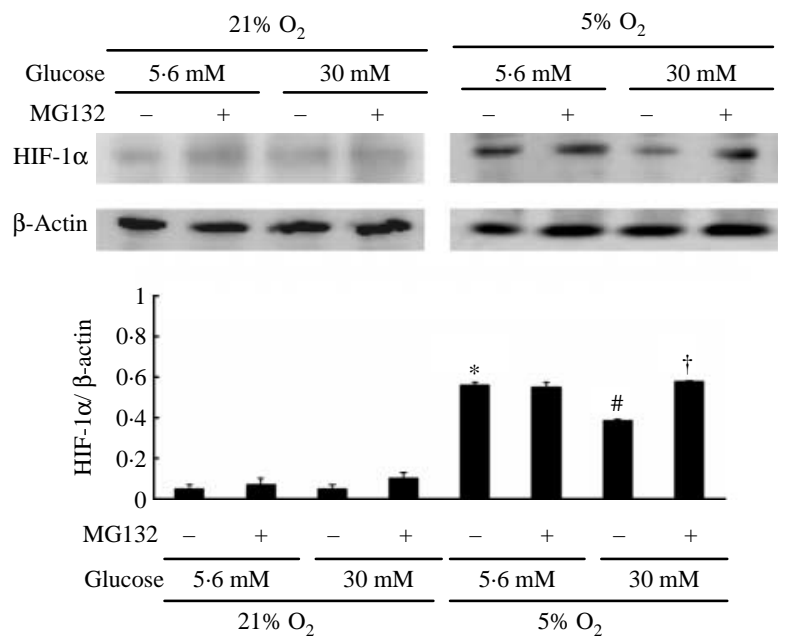

Figure 6 Effect of MG132, an inhibitor of proteasome activity, on the protein expression of HIF- $1 \alpha$ in mouse mesenchymal stem cells under normoxic or hypoxic conditions. MSCs were treated with normal glucose $(5.6 \mathrm{mM})$ or high glucose $(30 \mathrm{mM})$. After $24 \mathrm{~h}$, the cells were treated with or without $5 \mu \mathrm{M} \mathrm{MG} 132$ and incubated at normoxia $\left(21 \% \mathrm{O}_{2}\right)$ or in a hypoxic chamber $\left(5 \% \mathrm{O}_{2}\right)$ for $6 \mathrm{~h}$. HIF-1 $\alpha$ protein level was determined by western blot analysis. Representative ECL gel documents show the protein expression in MSCs. Bar graphs show quantitative analysis of the bands by densitometry. Values were normalized by the optical density values of $\beta$-actin bands. Data represent means \pm S.E.M. $(n=4)$. ${ }^{*} P<0.01$ versus MSCs treated with $5.6 \mathrm{mM}$ glucose at normoxia. ${ }^{\sharp} P<0 \cdot 01$ versus hypoxic MSCs treated with $5 \cdot 6 \mathrm{mM}$ glucose. ${ }^{\dagger} P<0 \cdot 01$ versus hypoxic MSCs treated with $30 \mathrm{mM}$ glucose. 

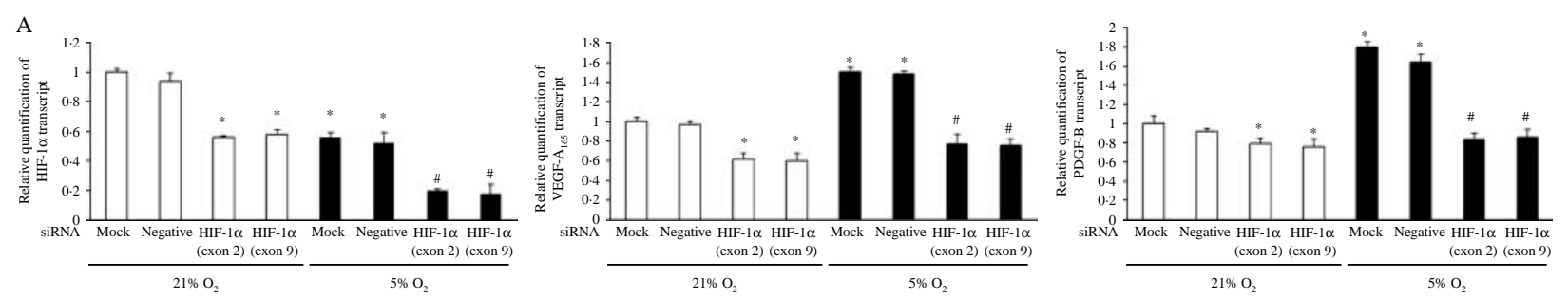

B

$21 \% \mathrm{O}_{2}$

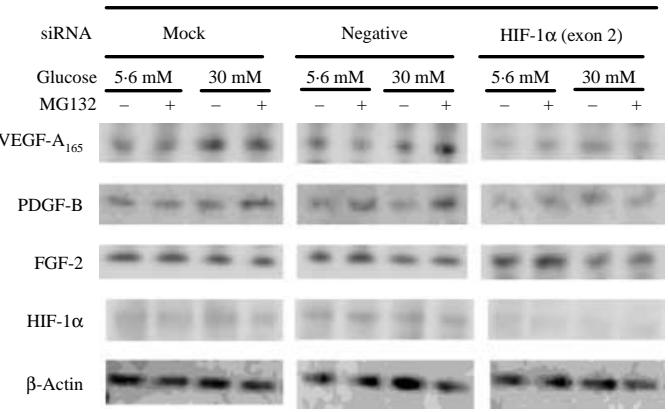

C
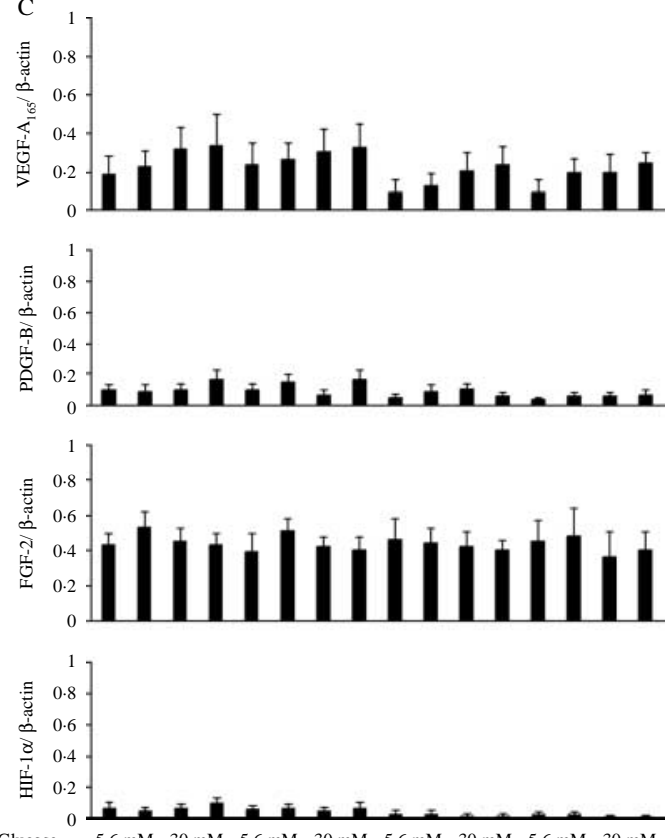

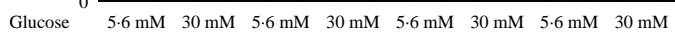

MG132

siRNA $\frac{5.6 \mathrm{mM}}{+} \frac{30 \mathrm{mM}}{-} \frac{5.6 \mathrm{mM}}{+} \frac{30 \mathrm{mM}}{+} \frac{5.6 \mathrm{mM}}{+} \frac{30 \mathrm{mM}}{+} \frac{5.6 \mathrm{mM}}{+} \frac{30 \mathrm{mM}}{+}$

Mock Negative $\overline{\operatorname{HIF}-1 \alpha(\text { exon } 2)} \overline{\operatorname{HIF}-1 \alpha(\text { exon 9) }}$

D

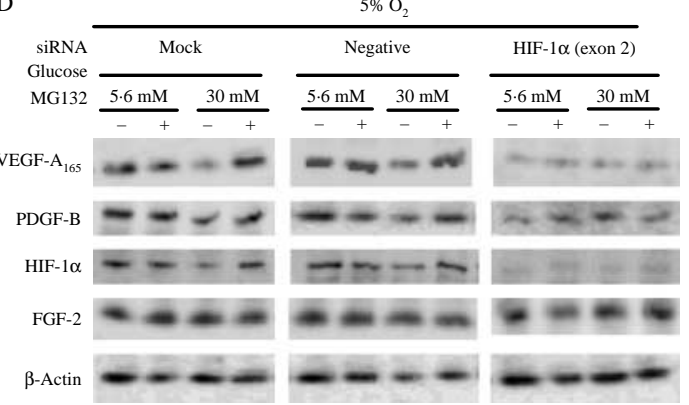

E
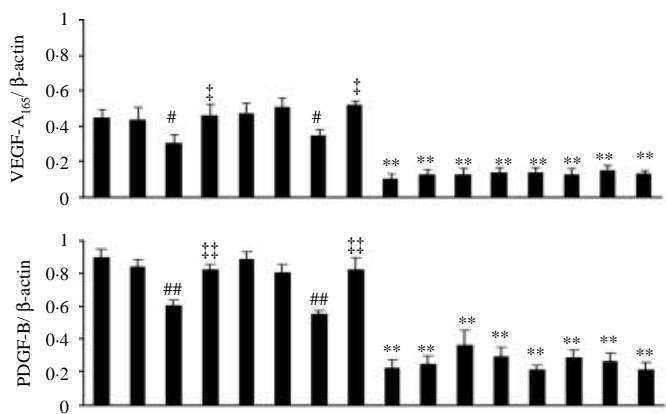

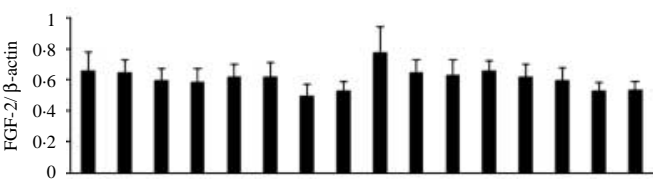

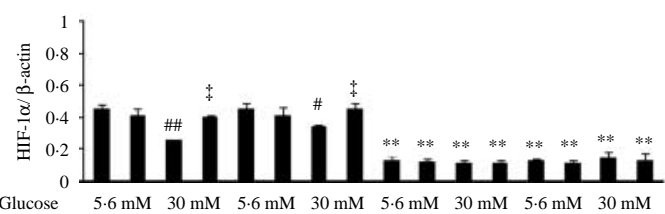

$\begin{array}{lllllllllllllllll}\text { Glucose } & 5.6 \mathrm{mM} & 30 \mathrm{mM} & 5.6 \mathrm{mM} & 30 \mathrm{mM} & 5.6 \mathrm{mM} & 30 \mathrm{mM} & 5.6 \mathrm{mM} & 30 \mathrm{mM}\end{array}$

MG132

siRNA

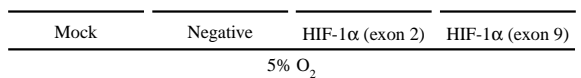

Figure 7 Effect of HIF- $1 \alpha$ siRNA on the expression of VEGF-A ${ }_{165}$ or PDGF-B in MSCs under normoxic or hypoxic conditions. Subconfluent MSCs were transfected with nontargeting siRNAs (negative), siRNA targeting HIF- $1 \alpha$ exon 2 or HIF- $1 \alpha$ exon 9. Mock control cells (mock) were subjected to transfection without oligonucleotides under the same conditions. After the transfection, cells were grown for $24 \mathrm{~h}$ and then exposed to normoxic or hypoxic conditions for $24 \mathrm{~h}$. (A) VEGF-A ${ }_{165}$, PDGF-B, and HIF-1 $\alpha$ transcript levels were determined using real-time RT-PCR and normalized to a control value (mock, $21 \% \mathrm{O}_{2}$ ). (B and D) Twenty-four hours after transfection, MSCs were treated with normal glucose $(5.6 \mathrm{mM})$ or high glucose $(30 \mathrm{mM})$. After $24 \mathrm{~h}$, the cells were treated with or without $5 \mu \mathrm{M} \mathrm{MG} 132$ and incubated at normoxia $(21 \%$ $\left.\mathrm{O}_{2}\right)$ or in a hypoxic chamber $\left(5 \% \mathrm{O}_{2}\right)$ for 6 h. VEGF-A ${ }_{165}$, PDGF-B, FGF-2, or HIF-1 $\alpha$ protein levels were determined by western blot analysis. Representative ECL gel documents show the protein expression in MSCs. (C and E) Bar graphs show quantitative analysis of the bands by densitometry. Values were normalized to the optical density values of $\beta$-actin bands. Data represent means \pm s.E.M. $(n=4)$. ${ }^{*} P<0 \cdot 05$; ${ }^{* *} P<0 \cdot 01$ versus normoxic MSCs transfected with nontargeting siRNA. ${ }^{\sharp} P<0 \cdot 05$; ${ }^{\sharp} P<0 \cdot 01$ versus hypoxic MSCs treated with $5 \cdot 6$ mM glucose. ${ }^{\ddagger} P<0 \cdot 05 ;{ }^{\ddagger \ddagger} P<0 \cdot 01$ versus hypoxic MSCs treated with $30 \mathrm{mM}$ glucose. 
treatment with MG132 did not affect HIF-1 $\alpha$ protein levels in normoxic MSCs.

As HIF- $1 \alpha$ may regulate the transcription of VEGF and PDGF in response to hypoxia, the attenuation of VEGF-A 165 and PDGF-B by a high-glucose concentration in hypoxic MSCs may be due to the decreased HIF-1 $\alpha$ protein level. To confirm this hypothesis, the role of HIF- $1 \alpha$ in the regulation of VEGF-A 165 or PDGF-B expression in MSCs by suppression of HIF- $1 \alpha$ using siRNA was studied. siRNA directed against HIF- $1 \alpha$ significantly inhibited the induction of HIF-1 $\alpha$ under hypoxic conditions (Fig. 7A, D, and E), but not under normoxia (Fig. 7B and C). Suppression of HIF-1 $\alpha$ using siRNA significantly attenuated the expression of VEGF-A $A_{165}$ and PDGF-B at mRNA and protein levels under hypoxic conditions (Fig. 7A, D, and E), whereas siRNA slightly attenuated the mRNA levels of VEGF-A 165 and PDGF-B under normoxia. In addition, HIF- $1 \alpha$ siRNA diminished the inhibition of HIF-1 $\alpha$, VEGF-A 165 , and
PDGF-B proteins by high-glucose concentrations in hypoxic MSCs. Although MG132 treatment reversed the inhibitory effect of high-glucose concentrations in MSCs transfected with the nontarget control siRNA, HIF-1 $\alpha$ siRNA diminished the preventive effect of MG132 (Fig. 7D and E).

Effect of 4-hydroxyl-tetramethylpiperidin-oxyl or Apocynin on VEGF- $A_{165}, P D G F-B$, or HIF- $1 \alpha$ expression in MSCs under hypoxic conditions

The effects of high concentrations of glucose or hypoxia have been associated with increased levels of ROS (Waypa et al. 2001, Brownlee 2005, Gao \& Wolin 2008). Therefore, we studied whether the inhibitory effect of a high-glucose concentration on HIF-1 $\alpha$ protein levels in hypoxic MSCs is due to increased ROS levels. A cell-permeable superoxide scavenger, 4-hydroxyl-tetramethylpiperidin-oxyl (Tempol; $100 \mu \mathrm{M}$ ), significantly reversed the glucose-induced attenuation of
A
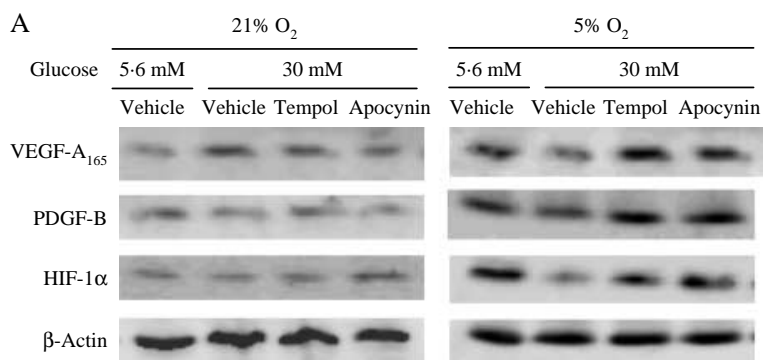

$\mathrm{C}$
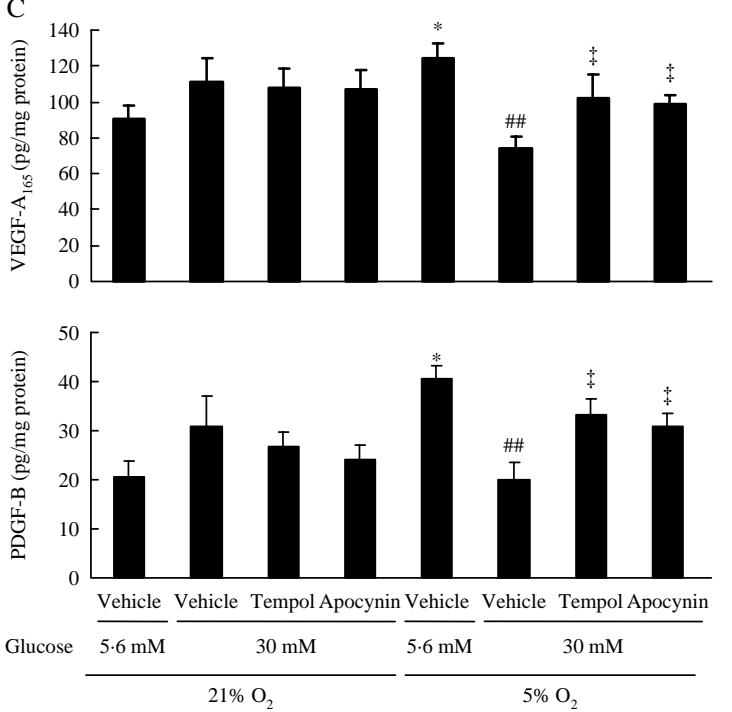

B
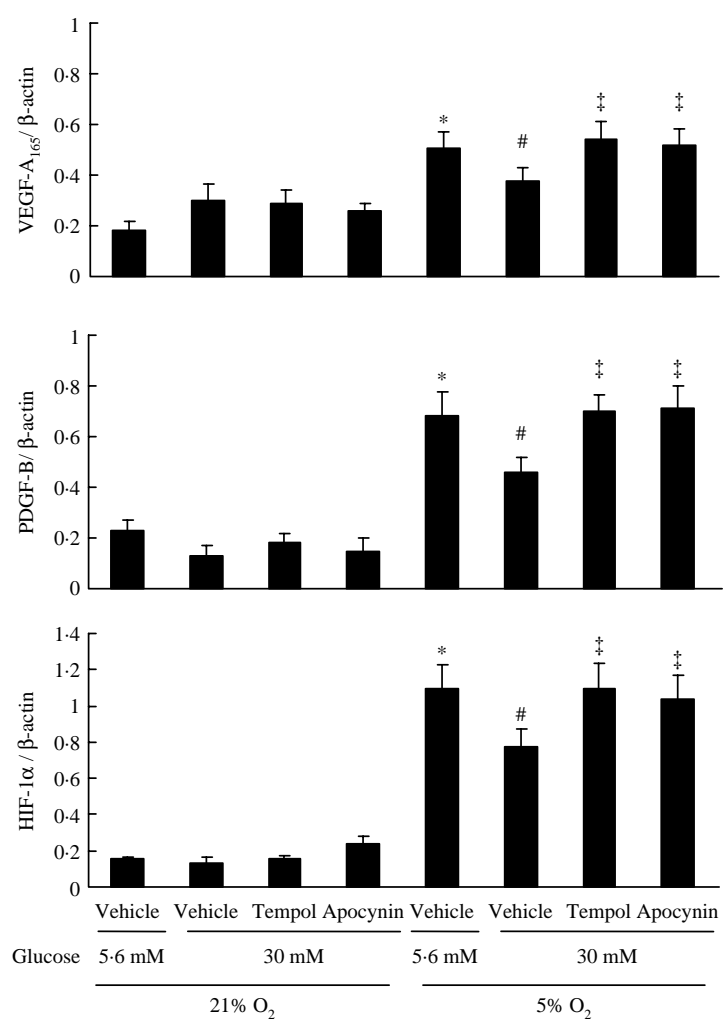

Figure 8 Effect of Tempol or Apocynin on VEGF-A ${ }_{165}$, PDGF-B, or HIF-1 $\alpha$ expression in MSCs stimulated by a high-glucose concentration under normoxic or hypoxic conditions. MSCs were treated with normal glucose (5.6 mM) or high glucose (30 mM). Tempol $(100 \mu \mathrm{M})$ or Apocynin $(1 \mathrm{mM})$ was added to the cells simultaneously. After $24 \mathrm{~h}$, the cells were incubated at normoxia $\left(21 \% \mathrm{O}_{2}\right)$ or in a hypoxic chamber $\left(5 \% \mathrm{O}_{2}\right)$ for $24 \mathrm{~h}$. VEGF-A ${ }_{165}$, PDGF-B, or HIF-1 $\alpha$ protein levels were determined by western blot analysis. (A) Representative ECL gels show protein expression in MSCs. (B) Bar graphs show quantitative analysis of the bands by densitometry. Values were normalized to the optical density values of $\beta$-actin bands. (C) The production of VEGF- $A_{165}$ or PDGF$B$ was determined by ELISA as the concentration of VEGF-A 165 or PDGF-B in the culture supernatants. Data represent means \pm S.E.M. $(n=4)$. ${ }^{*} P<0 \cdot 01$ versus MSCs treated with $5 \cdot 6 \mathrm{mM}$ glucose at normoxia. ${ }^{\sharp} P<0 \cdot 05 ;{ }^{\#} P<0 \cdot 01$ versus hypoxic MSCS treated with $5.6 \mathrm{mM}$ glucose. ${ }^{\ddagger} P<0.05$ versus hypoxic MSCs treated with $30 \mathrm{mM}$ glucose. 

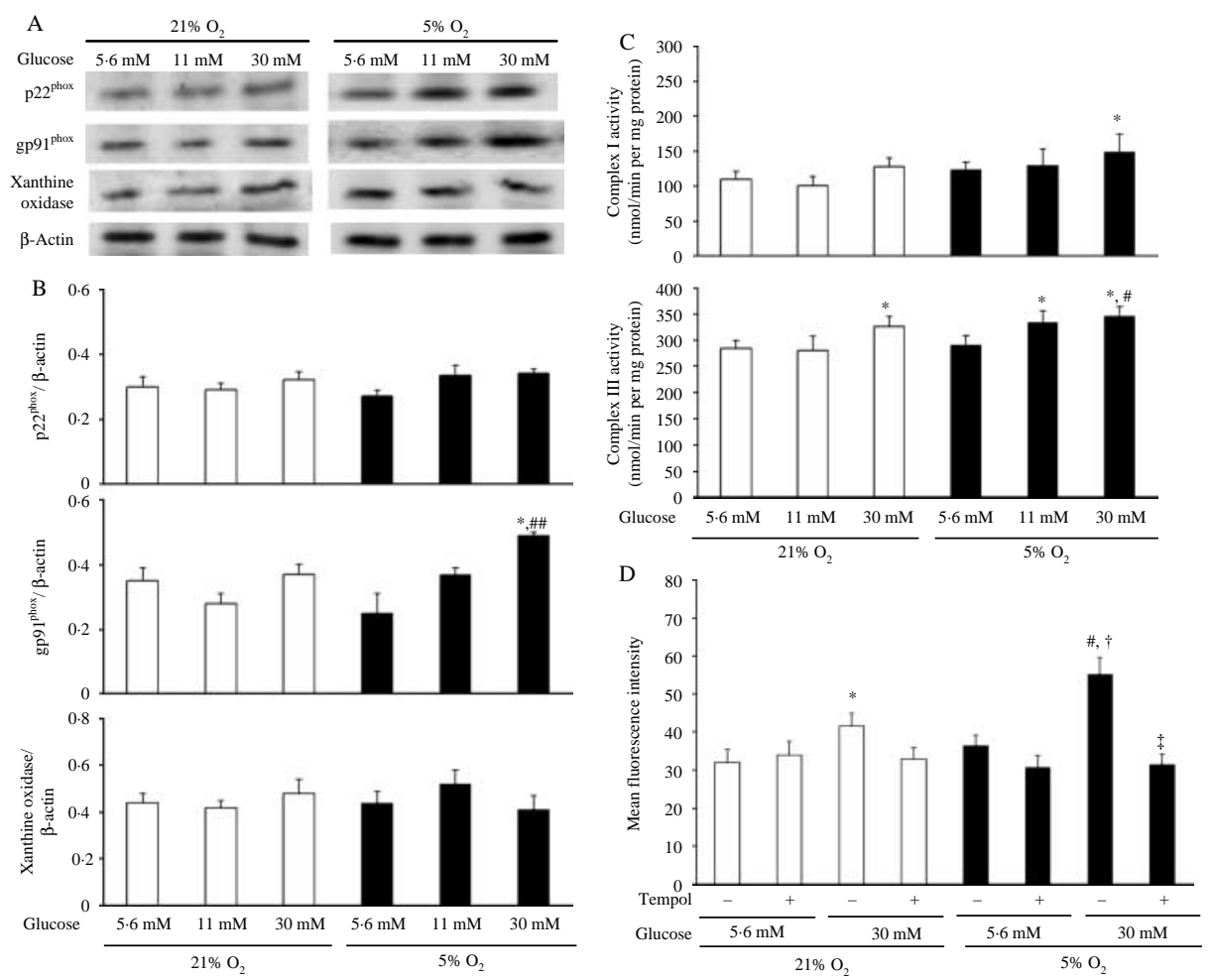

Figure 9 Effect of a high-glucose concentration on the expression of NADPH oxidase or xanthine oxidase, the activity of mitochondrial complexes I and III, and the intracellular superoxide level in MSCs under normoxic or hypoxic conditions. MSCs were treated with normal glucose $(5.6 \mathrm{mM})$ or high glucose $(11$ or $30 \mathrm{mM})$. After $24 \mathrm{~h}$, the cells were incubated under normoxic $\left(21 \% \mathrm{O}_{2}\right)$ or hypoxic $\left(5 \% \mathrm{O}_{2}\right)$ conditions for $24 \mathrm{~h}$. (A and B) The protein levels of $\mathrm{p} 22^{\text {phox }}, \mathrm{gp} 91^{\text {phox }}$, or xanthine oxidase were determined by western blot analysis. (A) Representative ECL gel documents show the protein expression in MSCs. (B) Bar graphs show quantitative analysis of the bands by densitometry. Values were normalized to the optical density values of $\beta$-actin bands. (C) Mitochondrial complexes I and III activity were measured in mitochondriaenriched fractions spectrophotometrically as described in section 'Materials and Methods'. (D) The intracellular superoxide levels were determined by flow cytometry as the fluorescence of ethidium using the dihydroethdium probe. Data were based on the mean fluorescence intensity of 5000 cells. Data represent means \pm S.E.M. $(n=4) .{ }^{*} P<0 \cdot 05$ versus normoxic MSCs treated with $5.6 \mathrm{mM}$ glucose. ${ }^{+} P<0 \cdot 05$ versus normoxic MSCs treated with $30 \mathrm{mM}$ glucose. ${ }^{\sharp} P<0 \cdot 05 ;{ }^{\#} P<0 \cdot 01$ versus hypoxic MSCs treated with $5.6 \mathrm{mM}$ glucose. ${ }^{\ddagger} P<0.05$ versus hypoxic MSCs treated with $30 \mathrm{mM}$ glucose.

VEGF-A 165 , PDGF-B, and HIF-1 $\alpha$ protein levels under hypoxic conditions (Fig. 8A and B). Apocynin (1 mM; an NADPH oxidase inhibitor) also significantly reversed the attenuation of VEGF-A 165 , PDGF-B, and HIF- $1 \alpha$ proteins levels induced by high-glucose concentrations. At normoxia, neither Tempol nor Apocynin affected the expression of VEGF-A 165 , PDGF-B, or HIF-1 $\alpha$ protein levels. Tempol or Apocynin significantly reversed the glucose-induced attenuation of VEGF-A 165 and PDGF-B production (Fig. 8C).

\section{Effect of a high-glucose concentration on the intracellular} superoxide level in MSCs under hypoxic conditions

$\mathrm{XO}$, NADPH oxidase, lipoxygenases, mitochondria, or the uncoupling of nitric oxide synthase can produce intracellular ROS. The expression and activity of NADPH oxidase were enhanced by a high-glucose concentration or hypoxia
(Muzaffar et al. 2005, Ebrahimian et al. 2006, Taye et al. 2010). In this study, we showed that stimulation with a highglucose concentration $(30 \mathrm{mM})$ significantly increased gp91 $91^{\text {phox }}$ expression in MSCs under hypoxic conditions (Fig. 9A and B), whereas a high-glucose concentration did not affect $\mathrm{p} 22^{\text {phox }}$ and $\mathrm{gp} 91^{\text {phox }}$ expression in MSCs at normoxia. A high-glucose concentration did not affect $\mathrm{XO}$ expression in MSCs under normoxic or hypoxic conditions (Fig. 9A and B). Mitochondrial superoxide was released from the electron respiratory chain via complexes I and III (Kudin et al. 2004), which were the main targets of hyperglycemia-induced injury (Rosca et al. 2005). This study showed that stimulation with a high-glucose concentration $(30 \mathrm{mM})$ slightly increased the activity of complexes I and III in MSCs under hypoxic conditions (Fig. 9C). In contrast, we could not detect lipoxygenases, nitric oxide synthases, or tetrahydrobiopterin in the cell lysates of MSCs 


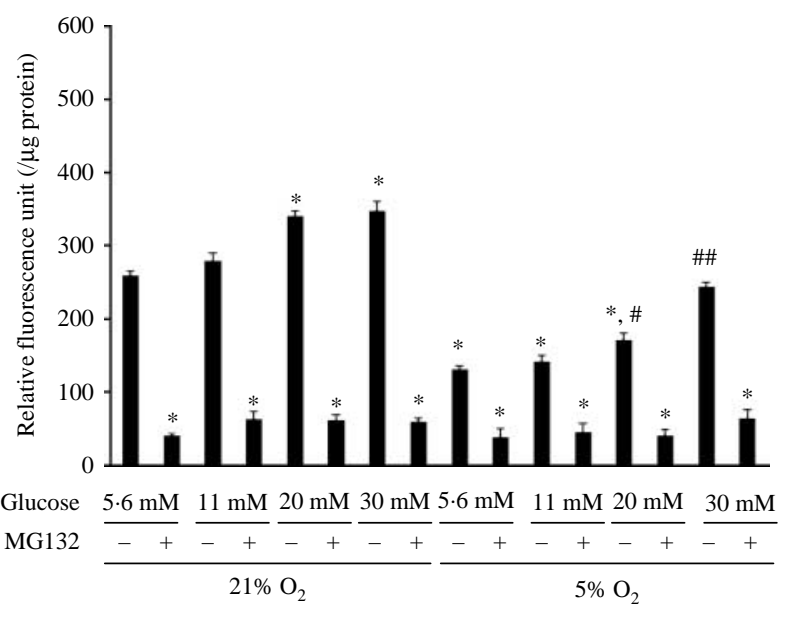

Figure 10 Effects of a high-glucose concentration on proteasome activity in mouse mesenchymal stem cells under normoxic or hypoxic conditions. MSCs were treated with normal glucose $(5 \cdot 6 \mathrm{mM})$ or high glucose $(11,20$, or $30 \mathrm{mM})$. After $24 \mathrm{~h}$, the cells were incubated at normoxia $\left(21 \% \mathrm{O}_{2}\right)$ or in a hypoxic chamber $\left(5 \% \mathrm{O}_{2}\right)$ for $24 \mathrm{~h}$.

Proteasome activity in the cell lysates was evaluated by the

Proteasome Activity Assay kit as described in section 'Materials and Methods'. Bar graphs show quantitative analysis of the cell lysates by the fluorometer. Data represent means \pm s.E.M. $(n=4) .{ }^{*} P<0 \cdot 01$ versus MSCs treated with $5 \cdot 6$ mM glucose at normoxia. ${ }^{\#} P<0 \cdot 05 ;{ }^{\# \#} P<0 \cdot 01$ versus hypoxic MSCs treated with $5.6 \mathrm{mM}$ glucose.

stimulated by a high-glucose concentration under normoxic or hypoxic conditions (data not shown).

Flow cytometry analysis using superoxide-sensitive dihydroethidium showed that stimulation with a high-glucose concentration $(30 \mathrm{mM})$ significantly increased intracellular superoxide level in MSCs at normoxia (Fig. 9D). Under hypoxic conditions, the effect of a high-glucose concentration $(30 \mathrm{mM})$ was significantly enhanced. Tempol significantly suppressed superoxide production when stimulated by a high-glucose level in hypoxic MSCs.

\section{Effect of a high-glucose concentration on proteasome activity in MSCs under hypoxic conditions}

We tested the hypothesis that the inhibitory effect of highglucose concentrations on the HIF-1 $\alpha$ protein levels in hypoxic MSCs was due to the enhancement of proteasomemediated degradation. Proteasome activity at a normal glucose concentration $(5.6 \mathrm{mM})$ under hypoxic conditions was significantly lower than that under normoxic conditions (Fig. 10). Stimulation with a high-glucose concentration recovered the decreased proteasome activity in hypoxic MSCs in a dose-dependent manner.

\section{Discussion}

This study demonstrates that in mouse MSCs, a high-glucose concentration significantly attenuated hypoxia-induced expression of HIF-1 $\alpha$, VEGF-A $\mathrm{A}_{165}$, and
PDGF-B (Figs 3, 5, and 6). Treatment with Tempol, a superoxide scavenger, significantly reversed the attenuation of HIF- $1 \alpha$, VEGF-A 165 , and PDGF-B by a high-glucose concentration (Fig. 8). This study also found that stimulation with a high-glucose concentration significantly increases intracellular superoxide levels and proteasome activity in hypoxic MSCs (Figs 9D and 10). Yang et al. (2003) showed that in rat renal medullary interstitial cells, superoxide generators significantly inhibited HIF- $1 \alpha$ levels induced by hypoxia or proteasome inhibitors and Tempol significantly increased HIF-1 $\alpha$ levels. In addition, treatment with MG132, a specific inhibitor of proteasome activity, significantly reversed the attenuation of HIF- $1 \alpha$ at the protein level by a high-glucose concentration (Fig. 6). Thus, in hypoxic MSCs, the increase in the intracellular superoxide level by stimulation with a high-glucose concentration may cause HIF- $1 \alpha$ degradation. HIF- $1 \alpha$ regulates the transcription of VEGF-A and PDGF-B under hypoxic conditions in cultured mouse cells (Nilsson et al. 2004, Copple et al. 2009). We found that the suppression of HIF-1 $\alpha$ using directed siRNA significantly attenuated the expression of VEGF-A $A_{165}$ and PDGF-B under hypoxic conditions (Fig. 8A-C). Although the inhibition of proteasomemediated degradation by MG132 treatment reversed the attenuation of HIF- $1 \alpha$, VEGF- $A_{165}$, and PDGF-B protein levels by a high-glucose concentration in hypoxic MSCs (Fig. 7D and E), HIF-1 $\alpha$ siRNA diminished the preventive effect of MG132. Thus, attenuation of hypoxia-induced VEGF- $A_{165}$ and PDGF-B expression may be due to the downregulation of hypoxia-induced HIF- $1 \alpha$ accumulation by glucose in high concentrations.

Stimulation with a high-glucose concentration $(30 \mathrm{mM})$ significantly increased intracellular levels of ROS in endothelial cells at normoxia (Brownlee 2005). We also showed that stimulation with a high-glucose concentration $(30 \mathrm{mM})$ significantly increased the activity of mitochondrial complex III and the intracellular superoxide level in MSCs under normoxic conditions (Figs 9C and 10). In contrast, severe hypoxia $\left(2 \% \mathrm{O}_{2}\right.$ or $\left.0 \% \mathrm{O}_{2}\right)$ alone increased the intracellular levels of ROS (Waypa et al. 2001, Gao \& Wolin 2008), whereas we showed that moderate hypoxia $\left(5 \% \mathrm{O}_{2}\right)$ did not affect the expression of NADPH oxidase and $\mathrm{XO}$, mitochondrial activity, or superoxide production (Figs 9 and 10). These disparate results may be due to the differences in the tested hypoxic conditions.

HIF- $1 \alpha$ mediates hypoxic induction of FGF- 2 mRNA and protein accumulation in human umbilical vein endothelial cells (Calvani et al. 2006). In hypoxic human breast carcinoma MCF-7/ADR cells, FGF-2 gene expression is mediated through the c-Jun $\mathrm{N}$-terminal kinase signal transduction pathway (Le \& Corry 1999). In this study, FGF-2 protein levels were not affected by high-glucose concentrations in hypoxic MSCs (Fig. 3A and B). Thus, FGF-2 expression in hypoxic MSCs may be HIF-1 $\alpha$ independent.

Recently, Weil et al. (2009) showed that severe hypoxia $\left(1 \% \mathrm{O}_{2}\right)$ enhanced the production of VEGF in human 
MSCs (hMSCs) by seven- to eight-fold, and that a highglucose concentration (20 or $30 \mathrm{mM}$ ) did not affect VEGF production in severe hypoxia-treated hMSCs. In contrast, we showed that moderate hypoxia $\left(5 \% \mathrm{O}_{2}\right)$ in MSCs yielded a 30\% increase in VEGF production compared with MSCs at normoxia, and that a high-glucose concentration $(30 \mathrm{mM})$ yielded a $30 \%$ decrease in VEGF production in MSCs under moderate hypoxic conditions. We speculate that, under severe hypoxia, the induction of VEGF may be greater than the attenuation of VEGF by high-glucose concentrations. In fact, no significant differences in intracellular superoxide level in MSCs treated with a highglucose concentration $(30 \mathrm{mM})$ were noted between the $5 \% \mathrm{O}_{2}$ and $1 \% \mathrm{O}_{2}$ concentrations (unpublished data). Thus, HIF-1 $\alpha$ degradation by stimulation with high-glucose concentrations in $1 \% \mathrm{O}_{2}$ may not be greater than that under $5 \% \mathrm{O}_{2}$.

We analyzed the effect of a high-glucose concentration in MSCs under hypoxic conditions for a short time (6 or $24 \mathrm{~h}$ ). In vivo studies by several investigators demonstrated that therapeutic angiogenesis was achieved $24 \mathrm{~h}$ after the implantation of bone-marrow-derived cells into ischemic regions (Kamihata et al. 2001, Onda et al. 2008). The therapeutic benefit of the cell therapy persists for several weeks. Thus, further studies will be required to reveal whether the effect of a high-glucose concentration in MSCs persists for longer periods under hypoxic conditions.

In summary, the current studies suggest that, in hypoxic MSCs, intracellular superoxide levels induced by a highglucose concentration may attenuate hypoxia-induced expression of HIF-1 $\alpha$, VEGF-A, and PDGF-B. The mechanism involved may serve to explain the fact that the paracrine effects of bone-marrow-derived cells under hypoxic conditions were impaired in diabetic patients. A high proportion of patients suffering acute stress such as stroke or myocardial infarction develop hyperglycemia, even in the absence of a preexisting diabetes diagnosis (Capes et al. 2001). Thus, acute hyperglycemia in patients with stroke or myocardial infarction may inhibit therapeutic angiogenesis by autologous bone-marrow-derived cells through induction of superoxide production. Cotreatment with antioxidants may ameliorate the impaired therapeutic efficacy.

\section{Declaration of interest}

The authors declare that there is no conflict of interest that could be perceived as prejudicing the impartiality of the research reported.

\section{Funding}

This work was supported by a grant-in-aid for the Special Research Program from the National Defense Medical College (No. 23) and the Scientific Research Program from the Japan Society for the Promotion of Sciences (No. 22500687) to TI, and by a grant from the Smoking Research Foundation (No. 23) to YW.

\section{Acknowledgements}

We are grateful to Prof. S Suzuki, Dr M Fujita, Dr S Takahashi, and M Uenoyama (Division of Environmental Medicine, National Defense Medical College Research Institute) for their valuable advice and support.

\section{References}

Bradford MM 1976 A rapid and sensitive method for the quantification of microgram quantities of protein utilizing the principle of protein-dye binding. Analytical Biochemistry 72 248-260. (doi:10.1016/0003$2697(76) 90527-3)$

Brownlee M 2005 The pathobiology of diabetic complications: a unifying mechanism. Diabetes 54 1615-1625. (doi:10.2337/diabetes.54.6.1615)

Calvani M, Rapisarda A, Uranchimeg B, Shoemaker RH \& Melillo G 2006 Hypoxic induction of an HIF- $1 \alpha$-dependent bFGF autocrine loop derives angiogenesis in human endothelial cells. Blood 107 2705-2712. (doi:10. 1182/blood-2005-09-3541)

Capes SE, Hunt D, Malmberg K, Pathak P \& Gerstein HC 2001 Stress hyperglycemia and prognosis of stroke in nondiabetic and diabetic patients. Stroke 32 2426-2432. (doi:10.1161/hs1001.096194)

Catrina SB, Okamoto K, Pereira T, Brismar K \& Poellinger L 2004 Hyperglycemia regulates hypoxia-inducible factor-1a protein stability and function. Diabetes 53 3226-3232. (doi:10.2337/diabetes.53.12.3226)

Ceradini DJ, Yao D, Grogan RH, Callaghan MJ, Edelstein D, Brownlee M \& Gurtner G 2008 Decreasing intracellular superoxide corrects defective ischemia-inducing new vessel formation in diabetic mice. Journal of Biological Chemistry 283 10930-10938. (doi:10.1074/jbc. M707451200)

Copple BL, Bustamante JJ, Welch TP, Kim ND \& Moon JO 2009 Hypoxiainducible factor-dependent production of profibrotic mediators by hypoxic hepatocytes. Liver International 29 1010-1021. (doi:10.1111/j.1478-3231. 2009.02015.x)

Ebrahimian TG, Heymes C, You D, Blanc-Brude O, Mees B, Waeckel L, Duriez M, Vilar J, Brandes RP, Levy BI et al. 2006 NADPH oxidasederived overproduction of reactive oxygen species impairs postischemic neovascularization in mice with type 1 diabetes. American Journal of Pathology 169 719-728. (doi:10.2353/ajpath.2006.060042)

Gao Q \& Wolin MS 2008 Effects of hypoxia on relationship between cytosolic and mitochondrial NADPH redox and superoxide generation in coronary arterial smooth muscle. American Journal of Physiology. Heart and Circulatory Physiology 295 H978-H989. (doi:10.1152/ajpheart.00316.2008)

Hirata K, Li TS, Nishida M, Ito H, Matsuzaki M, Kasaoka S \& Hamano K 2003 Autologous bone marrow cell implantation as therapeutic angiogenesis for ischemic hindlimb in diabetic rat model. American Journal of Physiology. Heart and Circulatory Physiology 284 H66-H70. (doi:10.1152/ ajpheart.00547.2002)

Janssen AJM, Trijbels FJM, Sengers RCA, Smeitink JAM, van den Heuvel LP, Wintjes LTM, Stoltenborg-Hogenkamp BJM \& Rodenburg RJT 2007 Spectrophotometric assay for complex I of the respiratory chain in tissue samples and cultured fibroblasts. Clinical Chemistry $\mathbf{5 3}$ 729-734. (doi:10. 1373/clinchem.2006.078873)

Jarreta D, Orus J, Barrientos A, Miro O, Roig E, Heras M, Moraes CT, Cardellach F \& Casademont J 2000 Mitochodrial function in heart muscle from patients with idiopathic dilated cardiomyopathy. Cardiovascular Research 45 860-865. (doi:10.1016/S0008-6363(99)00388-0)

Kallio PJ, Wilson WJ, O’Brien S, Makino Y \& Poellinger L 1999 Regulation of the hypoxia-inducible transcription factor $1 \alpha$ by the ubiquitinproteasome pathway. Journal of Biological Chemistry 274 6519-6525. (doi:10. $1074 / \mathrm{jbc} .274 .10 .6519)$

Kamihata H, Matsubara H, Nishiue T, Fujiyama S, Tsustsumi Y, Ozono R, Masaki H, Mori Y, Iba O, Tateishi E et al. 2001 Implantation of bone marrow mononuclear cells into ischemic myocardium enhances collateral perfusion and regional function via side supply of angioblasts, angiogenic ligands, and cytokines. Circulation 104 1046-1052. (doi:10.1161/hc3501. 093817) 
Kinnaird T, Stabile E, Burnett MS, Lee CW, Shou M, Barr S, Fuchs S \& Epstein SE 2004a Local delivery of marrow-derived stromal cells augments collateral perfusion through paracrine mechanisms. Circulation 109 1543-1549. (doi:10.1161/01.CIR.0000124062.31102.57)

Kinnaird T, Stabile E, Burnett MS, Lee CW, Barr S, Fuchs S \& Epstein SE $2004 b$ Marrow-derived stromal cells express genes encoding a broad spectrum of arteriogenic cytokines and promote in vitro and in vivo arteriogenesis through paracrine mechanisms. Circulation Research 94 678-685. (doi:10.1161/01.RES.0000118601.37875.AC)

Kudin AP, Bimpong-Buta NYB, Vielhaber S, Elger CE \& Kunz WS 2004 Characterization of superoxide-producing sites in isolated brain mitochondria. Journal of Biological Chemistry 279 4127-4135. (doi:10.1074/jbc. M310341200)

Le YJ \& Corry PM 1999 Hypoxia-induced bFGF gene expression is mediated through the JNK signal transduction pathway. Molecular and Cellular Biochemistry 202 1-8. (doi:10.1023/A:1007059806016)

Li TS, Furutani A, Takahashi M, Ohshima M, Qin SL, Kobayashi T, Ito H \& Hamano K 2006 Impaired potency of bone marrow mononuclear cells for inducing therapeutic angiogenesis in obese diabetic rats. American Journal of Physiology. Heart and Circulatory Physiology 290 H1362-H1369. (doi:10. 1152/ajpheart.00766.2005)

Meng L, Mohan R, Kwok BH, Elofsson M, Sin N \& Crews CM 1999 Epoxomicin, a potent and selective proteasome inhibitor, exhibits in vivo anti-inflammatory activity. PNAS 96 10403-10408. (doi:10.1073/pnas.96. 18.10403)

Muzaffar S, Shukla N, Angelini GD \& Jeremy JY 2005 Acute hypoxia simultaneously induces the expression of gp $91^{\text {phox }}$ and endothelial nitric oxide synthase in the porcine pulmonary artery. Thorax $60305-313$. (doi:10.1136/thx.2003.018796)

Nilsson I, Shibuya M \& Wennstrom S 2004 Differential activation of vascular genes by hypoxia in primary endothelial cells. Experimental Cell Research $\mathbf{2 9 9}$ 476-485. (doi:10.1016/j.yexcr.2004.06.005)

Odano I, Tsuchiya T, Nishihara M, Sakai K, Abe H \& Tanaka R 1993 Regional cerebral blood flow measured with $\mathrm{N}$-isopropyl-p- [123I] iodoamphetamine and its redistribution in ischemic cerebrovascular disease. Stroke 24 1167-1172.

Onda T, Honmou O, Harada K, Houkin K, Hamada H \& Kocsis JD 2008 Therapeutic benefits by human mesenchymal stem cells (hMSCs) and Ang1 gene-modified hMSCs after cerebral ischemia. Journal of Cerebral Blood Flow and Metabolism 28 329-340. (doi:10.1038/sj.jcbfm.9600527)

Peister A, Mellad JA, Larson BL, Hall BM, Gibson LF \& Prockop DJ 2004 Adult stem cells from bone marrow (MSCs) isolated from different strains of inbred mice vary in surface epitopes, rates of proliferation, and differentiation potential. Blood 103 1662-1668. (doi:10.1182/blood-2003-09-3070)

Rosca MG, Mustata TG, Kinter MT, Ozdemir AM, Kern TS, Szweda LI, Brownlee M, Monnier VM \& Weiss MF 2005 Glycation of mitochondrial proteins from diabetic rat kidney is associated with excess superoxide formation. American Journal of Physiology. Renal Physiology 289 F420-F430. (doi:10.1152/ajprenal.00415.2004)

Salceda S \& Caro J 1997 Hypoxia-inducible factor $1 \alpha($ HIF- $1 \alpha)$ protein is rapidly degraded by the ubiquitin-proteasome system under normoxic condition. Its stabilization by hypoxia depends on redox-induced changes. Journal of Biological Chemistry 272 22642-22647. (doi:10.1074/jbc.272.36.22642)

Sharikabad MN, Ostbye KM, Lyberg T \& Brors O 2001 Effect of extracellular $\mathrm{Mg}^{2+}$ on ROS and $\mathrm{Ca}^{2+}$ accumulation during reoxygenation of rat cardiomyocytes. American Journal of Physiology. Heart and Circulatory Physiology $280 \mathrm{H} 344-\mathrm{H} 353$.

Sica V, Williams-Ignarro S, de Nigris F, D'Armiento FP, Lerman LO, Balestrieri ML, Maiane C, Palagiano A, Rossello L, Ignarro LJ et al. 2006 Autologous bone marrow cell therapy and matabolic intervention in ischemia-induced angiogenesis in the diabetic mouse hindlimb. Cell Cycle $\mathbf{5}$ 2903-2908.

Stamm C, Westphal B, Kleine HD, Petzsch M, Kittner C, Klinge H, Schnumichen C, Nienaber CA, Freund M \& Steinhoff G 2003 Autologous bone marrow stem cell transplantation for myocardial regeneration. Lancet 361 45-46. (doi:10.1016/S0140-6736(03)12110-1)
Strauer BE, Brehm M, Zeus T, Kostering M, Hernandez A, Sorg RV, Kogler G \& Wernet P 2002 Repair of infracted myocardium by autologous intracoronary mononuclear bone marrow cell transplantation in humans. Circulation 106 1913-1918. (doi:10.1161/01.CIR.0000034046. 87607.1C)

Tamarat R, Silvestre JS, Le Ricousse-Roussanne S, Barateau V, LecornteRaclet L, Clergue M, Duriez M, Tobelem G \& Levy BI 2004 Impairment in ischemia-induced neovascularization in diabetes. Bone marrow mononuclear cell dysfunction and therapeutic potential of placenta growth factor treatment. American Journal of Pathology 164 457-466.

Tang YL, Zhao Q, Zhang YC, Cheng L, Liu M, Shi J, Yang YZ, Pan C, Ge J \& Phillips MI 2004 Autologous mesenchymal stem cell transplantation induce VEGF and neovascularization in ischemic myocardium. Regulatory Peptides 117 3-10. (doi:10.1016/j.regpep.2003.09.005)

Tateishi-Yuyama E, Matsubara H, Murohara T, Ikeda U, Shintani S, Masaki H, Amano K, Kishimoto Y, Yoshimoto K, Akashi H et al. 2002 Therapeutic angiogenesis for patients with limb ischemia by autologous transplantation of bone marrow cells: a pilot study and a randomized controlled trial. Lancet 360 427-435. (doi:10.1016/S0140-6736(02)09670-8)

Taye A, Saad AH, Kumar AH \& Morawietz H 2010 Effect of apocynin on NADPH oxidase-mediated oxidative stress-LOX-1-eNOS pathway in human endothelial cells exposed to high glucose. European Journal of Pharmacology 627 42-48. (doi:10.1016/j.ejphar.2009.10.045)

Wang M, Crisostomo PR, Herring C, Meldrum KK \& Meldrum DR 2006 Human progenitor cells from bone marrow or adipose tissue produce VEGF, HGF, and IGF-1 in response to TNF by a p38 MAPK-dependent mechanism. American Journal of Physiology. Regulatory, Integrative and Comparative Physiology 291 R880-R884. (doi:10.1152/ajpregu.00280. 2006)

Wang M, Zhang W, Crisostomo P, Markel T, Meldrum KK, Fu XY \& Meldrum DR 2007 STAT3 mediates bone marrow mesenchymal stem cell VEGF production. Journal of Molecular and Cellular Cardiology $\mathbf{4 2}$ 1009-1015. (doi:10.1016/j.yjmcc.2007.04.010)

Waypa GB, Chandel NS \& Schumacker PT 2001 Model for hypoxic pulmonary vasoconstriction involving mitochondrial oxygen sensing. Circulation Research 88 1259-1266. (doi:10.1161/hh1201.091960)

Weil BR, Abarbanell AM, Herrmann JL, Wang Y \& Meldrum DR 2009 High glucose concentration in cell culture medium does not acutely affect human mesenchymal stem cell growth factor production or proliferation. American Journal of Physiology. Regulatory, Integrative and Comparative Physiology 296 R1735-R1743. (doi:10.1152/ajpregu.90876.2008)

Xia L, Wang H, Munk S, Frecker H, Goldberg HJ, Fantus IG \& Whiteside CI 2007 Reactive oxygen species, PKC-b1, and PKC-z mediate high-glucoseinduced vascular endothelial growth factor expression in mesangial cells. American Journal of Physiology. Endocrinology and Metabolism 293 E1280-E1288. (doi:10.1152/ajpendo.00223.2007)

Yang ZZ, Zhang AY, Yi FX, Li PL \& Zou AP 2003 Redox regulation of HIF-1 $\alpha$ levels and HO-1 expression in renal medullary interstitial cells. American Journal of Physiology. Renal Physiology 284 F1207-F1215. (doi:10. 1152/ajprenal.00017.2002)

Yoshioka T, Ageyama N, Shibata H, Yasu T, Misawa Y, Takeuchi K, Matsui K, Yamamoto K, Terao K, Shimada K et al. 2005 Repair of infarcted myocardium mediated by transplanted bone marrow-derived CD34 + stem cells in a nonhuman primate model. Stem Cells 23 355-364. (doi:10.1634/ stemcells.2004-0200)

Received in final form 12 October 2010

Accepted 10 November 2010

Made available online as an Accepted Preprint 10 November 2010 